\title{
The Relationship between Portuguese Adolescent Perception of Parental Styles, Social Support, and School Behaviour
}

\author{
José Castro Silva, José Morgado, João Maroco \\ UIPCDE, ISPA-IU, Lisbon, Portugal \\ Email: jcsilva@ispa.pt
}

Received February $1^{\text {st }}$, 2012; revised March $3^{\text {rd }}, 2012$; accepted April $4^{\text {th }}, 2012$

\begin{abstract}
The present article describes preliminary results of a study that aims to analyse the relationship among Portuguese adolescent perception of parental styles, social support received from family and peers and their school behaviour. Participants were 537 adolescents aged between 14 and 16. The "Parental Authority Questionnaire", the "Perceived Social Support-Friends Scale" and "Perceived Social Support-Family Scale" were used to measure adolescent perceptions. Overall, Portuguese adolescents perceive their parents as using predominantly a democratic parental style. Associations between school behaviour and parental styles show that "well-behaved" adolescents perceive their parents as less permissive. On the other hand, adolescents who misbehave perceive their parents as more permissive and authoritarian. As regards the relationship between perceived school behaviour and social support, adolescents recognise receiving greater support from peers than from family, and adolescents who "often behave badly" are those who refer to receiving less social support, either from the family or peers.
\end{abstract}

Keywords: Parenting Styles; Social Support; Adolescence

\section{Introduction}

In modern school communities classroom misbehavior seems to be a recurring concern of professionals, often appearing associated with school failure, dropouts and social exclusion. Traditionally, talk about the causality of misbehavior refers to individual and family factors as strong contributory factors to school behavior. Therefore seems pertinent to enhance the study of the existing relationships between family dynamics and adolescent behavior. Likewise, there is no empirical evidence on the relationship between the perception of Portuguese adolescents about parenting styles, social support and their behavior in school settings.

As a first major objective, we aim to verify whether Portuguese adolescent school behavior relates to, and in what way, their perception of parental styles. On the other hand, considering individual adjustments that occur in adolescence, we established as a second goal to study whether Portuguese adolescent school behavior relates to their perception of social support from their family and friends. In addition to these two major objectives, we aim to look at what impact gender and the level of schooling of the parents may have on Portuguese adolescent perceptions of parental styles, social support received from family and social support received from peers.

\section{Parental Styles}

The study of the styles of education used by families and the impact on children has increased greatly since the work developed in the 1960s by Baumrind, which supports the definition of a model accommodating four parental styles (Baumrind, 1967) based on different combinations of two basic dimensions, control and affection.

Darling and Steinberg (1993) define parental style as corre- sponding to the emotional atmosphere in which parents raise children, and it is also characterized by the dimensions of responsiveness and demands (Baumrind, 1991). Thus, and in agreement with several authors (e.g. Alcón, 2002; Baumrind, 1991; Cole \& Cole, 2001; Dornbusch, Ritter, Leiderman, Robert, \& Fraleigh, 1987, Matta, 2001; Palacios, 2000; Schaffer, 1996), we can highlight the authoritarian, permissive, democratic and rejecting/negligent styles. Due to methodological reasons and prevalence, we did not consider the last style. It is important to note that the literature identifies other models for analyzing parental styles, including the theoretical perspective developed by Steinberg which also includes four different styles: authoritarian, authoritative, indulgent and uninvolved (Durbin, D. L., Darling, N., Steinberg, L., \& Brown, B. B., 1993).

Briefly, data from several studies show that children educated within an authoritarian parental style appear to show lower levels of autonomy and social responsibility (Alcón, 2002; Dornbusch et al., 1987), use of more aggressive behavior, lower self-esteem and lower social competence (Alcón, 2002; Palacios, 2000) and present a tendency to organize their behavior on the basis of a punishment and reward system (Alcón, 2002; Matta, 2001).

Children educated by parents within a permissive style are less autonomous and present a lower level of social responsibility (Dornbusch et al., 1987; Palacios, 2000; Cole \& Cole, 2001) and low assertiveness (Alcón, 2002).

In general, children educated by parents using a democratic style reveal better emotional and socio-cognitive skills (Alcón, 2002; Baumrind, 1973; Matta, 2001; Morris, Silk, Steinberg, Myers, \& Robinson, 2007; Palacios, 2000; Steinberg, 2001). In accordance with Yeh and Lempers (2004), a democratic parental style, particularly in adolescence, enhances the individual's abilities to manage negative or threatening experiences, sig- 
nificant events and relationships with partners effectively.

Generally, the influence of the parental style tends to preserve during adolescence (Baumrind, 1991, 2005; Glasgow et al., 1997), in particular the level of autonomy, social behavior and school performance (e.g., Baumrind, 1967; Bernier, Larose, Boivin, \& Soucy, 2004; Dornbusch et al., 1987; Fontaine, 1995; Grolnick, 2003; Lamborn et al., 1991; Steinberg, L., Elmen, J. D., \& Mounts, N. S., 1989; Steinberg, L., Mounts, N. S., Lamborn, S. D., \& Dornbusch, S. M., 1991; Smetana, 1995).

Taking into account that one of the objectives of the present research is to analyze how adolescents perceive social support received from family and peers, some theoretical aspects relating to this issue are explained below.

\section{Social Support}

Regarding the nature of the relationships established with family and peers, as well as changes throughout their development, individuals tend to show a different perception of social support obtained in each group (Procidano \& Hellen, 2000). Within this framework, it is important to emphasize the importance of the adolescent's perception of social support in changing processes as they occur during adolescence (e.g., Antunes \& Fontaine, 2004; Ciariano, Kliewer, Bonino, \& Bosma, 2008). However, we must emphasize that social support needs vary individually (Brendt, 1989).

Also, it is pertinent to highlight the qualitative relationship between the social support provided by family and by peers: namely, lower perceived social support by the family will correspond to the adolescent seeking more social support from their peers (Noller, 1990) or, in a different formulation, the quality of family social support influences the quality of the relationships within the group of peers (Colarossi \& Eccles, 2000).

On the other hand, Wills and Cleary (1996) found a close relationship between disruptive school behavior and low family social support, an association also cited in Crosnoe e Elder (2004) and Matherne e Thomas (2001). Also, Fonseca (2002) refers to adolescents exposed to inconsistent parental models are less involved and actively or passively hostile. They may participate in risk groups with behavior problems, show addictive behavior and have a more fragile psychological structure. In summary, adolescent perception of effective social support either from family or peers plays a crucial role in the individual's development in adolescence (Strecht, 2005).

\section{Method}

\section{Participants}

The participants were part of a convenience sample of 258 male and 279 female Portuguese adolescents from several urban schools in Portugal. They ranged in age from 14 to 16 years old.

\section{Procedure}

Aiming to define "School behavior", we requested classroom teachers to assess the participants' behavior commonly observed, as described in Table $\mathbf{1}$.

The level of the parents' schooling was organized into three groups, as seen in Table 2: "Basic" corresponds to school attendance up to year 9; "Middle" from year 10 to 12 and,
"Higher" to the completion of higher education.

Considering the objectives of the study and its theoretical framework, the Parental Authority Questionnaire (PAQ) by Buri (1991) was used as an instrument in order to assess the "parental style" perceived by subjects, as well as the scales "Perceived Social Support-Family Scale" (PSS-Fa) and "Perceived Social Support-Friends Scale” (PSS-Fr) by Procidano e Heller (1983) to assess perceived "social support" by participants in relationship to the family and peers.

\section{Instruments}

The scales have been translated and adapted for Portuguese studies, and their psychometric properties are acceptable, as shown in Table 3.

In accordance with the theoretical model by Baumrind (1967), PAQ consists of 30 items formulated in a Likert type scale with five points distributed between "I totally agree" to "I totally disagree” and grouped into three sub-scales corresponding to parental styles: "permissive", "democratic" and "authoritarian". Values between 10 and 50 points in each sub-scale may be obtained and the perception of parental style is determined by using the highest sub-scale value.

The PSS-Fa and PSS-Fr consist of 20 items with three answer options- “yes", "no" and "don't know"-and are weighted from 0 to 20 (the response "don't know" carries a weight of 0 ). Values closest to 20 suggest a high perception of social support and values below 10 indicate a low perception of social support.

The Statistical Package for Social Sciences (SPSS Windows, version 18.0) was used to analyze data. According to the nature of the data and the objectives of the work, additional descriptive statistical comparisons were carried out by using the t-test and multivariate analysis of variance (MANOVA).

\section{Results}

In general, the data show (see Table 4) that adolescents perceive their parents as using predominantly "democratic", "authoritarian” or "permissive” styles and this perception displays

Table 1.

School behaviour.

\begin{tabular}{cccc}
\hline $\begin{array}{c}\text { Always well } \\
\text { behaved }\end{array}$ & $\begin{array}{c}\text { Reasonably well } \\
\text { behaved }\end{array}$ & $\begin{array}{c}\text { Often badly } \\
\text { behaved }\end{array}$ & Total \\
\hline 239 & 206 & 92 & 537 \\
\hline
\end{tabular}

Table 2.

Level of the parents' schooling.

\begin{tabular}{ccc}
\hline Basic & Middle & Higher \\
\hline 245 & 189 & 99 \\
\hline
\end{tabular}

Table 3.

Internal consistency of instruments—cronbach's alpha.

\begin{tabular}{|c|c|c|}
\hline \multicolumn{2}{|c|}{ Perceived Social Support-Family Scale (PSS-Fa) } & 0.850 \\
\hline \multicolumn{2}{|c|}{ Perceived Social Support-Friends Scale (PSS-Fr) } & 0.810 \\
\hline \multirow{4}{*}{$\begin{array}{l}\text { Parental Authority } \\
\text { Questionnaire (PAQ) }\end{array}$} & Sub-scales & \\
\hline & Parental Style: authoritarian & 0.769 \\
\hline & Parental Style: permissive & 0.660 \\
\hline & Parental Style: democratic & 0.779 \\
\hline
\end{tabular}


quite similar values, although the "permissive" style presents a slightly lower value.

Also, in agreement with the data shown in Table 5, the adolescents, when questioned, perceive themselves as obtaining more social support from peers than from family.

Below are presented data in agreement with the definition of this study's goals (Table 6).

Concerning the relationship between adolescent school behavior and their perception of the parenting styles of their parents, we see that:

- The democratic style is predominant;

- The permissive style is perceived with the lowest values;

- Adolescents who behave better at school perceive their parents as less permissive;

- As school behavior deteriorates, adolescents perceive their parents as more permissive or more authoritarian.

Statistical analysis shows significant differences (Pillae' Trace $=0.067 ; \mathrm{F}(6,1032)=5.939 ; p<0.001)$. These differences appear in "Authoritarian style" $(\mathrm{F}(2,517)=7.118 ; p=$ $0.001)$ and in "Permissive style" $(\mathrm{F}(2,517)=9.116 ; p<0.001)$. With respect to the perception of "authoritarian style", we found differences between the group "always well-behaved" and the other two groups with values of $p=0.002$ for the group "reasonably well behaved", and $p=0.017$ for the group "Often badly behaved".

When we consider the relationship between behavior at school and perceived social support, according to the data presented in Table 7, we see that, irrespective of behavior at school, adolescents perceive more social support from their peers than from their family.

It is also relevant to emphasize the fact that adolescents with less positive behavior showed the lowest perception of social

Table 4.

Global data—perceived parenting styles.

\begin{tabular}{cccc}
\hline Parenting style & N & M & Sd \\
\hline Authoritarian & 531 & 30.25 & 6.509 \\
Permissive & 530 & 28.93 & 5.681 \\
Democratic & 520 & 37.04 & 6.194 \\
\hline
\end{tabular}

Table 5.

Global data—perceived social support.

\begin{tabular}{cccc}
\hline & $\mathrm{N}$ & $\mathrm{M}$ & $\mathrm{Sd}$ \\
\hline Family support & 529 & 13.04 & 4.599 \\
Peers support & 526 & 14.81 & 3.814 \\
\hline
\end{tabular}

Table 6.

School behavior and perceived parenting style.

\begin{tabular}{|c|c|c|c|c|c|c|c|c|c|}
\hline \multirow{2}{*}{ Behaviour } & \multicolumn{3}{|c|}{ Permissive style } & \multicolumn{3}{|c|}{ Democratic style } & \multicolumn{3}{|c|}{ Authoritarian style } \\
\hline & $\mathrm{N}$ & M & Sd & $\mathrm{N}$ & M & Sd & $\mathrm{N}$ & M & Sd \\
\hline $\begin{array}{l}\text { Always } \\
\text { well } \\
\text { behaved }\end{array}$ & 236 & 27.79 & 5.073 & 237 & 36.68 & 5.848 & 237 & 29.14 & 5.945 \\
\hline $\begin{array}{l}\text { Reasonably } \\
\text { well } \\
\text { behaved }\end{array}$ & 204 & 29.84 & 5.893 & 204 & 37.05 & 6.497 & 202 & 31.29 & 6.777 \\
\hline $\begin{array}{l}\text { Often } \\
\text { badly } \\
\text { behaved }\end{array}$ & 90 & 29.86 & 6.204 & 92 & 37.91 & 6.353 & 92 & 31.39 & 6.509 \\
\hline
\end{tabular}

support either from the family or from peers.

The data below relating to the variable "level of parent schooling” are analyzed, and directly relate to a relationship with the "perceived parenting styles".

In agreement with Table 8, we can see:

- "Democratic" emerges as the predominant parenting style;

- Independently from the level of schooling, parents are always perceived as more authoritarian than permissive;

- Parents who have only completed "basic education" are perceived as the least "democratic";

- Parents who have completed higher schooling are perceived as the least permissive and authoritarian.

Statistical analysis demonstrates significant differences (Pillae' Trace $=0.026 ; \mathrm{F}(6,1024)=2.216 ; p=0.039)$. A difference emerges in the group that perceives "Democratic style" (F $(2,513)=3.167 ; p=0.043)$. Moreover, there is a significant difference between the group "basic schooling level" and the group "middle schooling level”, $(p=0.038)$.

As regards the relationship between "level of schooling" and perceived "social support” (see Table 9), we can see that:

- Adolescents, irrespective of the level of schooling of the parents, consider that they obtain more social support from their peers than from their family.

- Adolescents whose parents are of a "higher schooling level" admit to obtaining more social support from their family than from their colleagues whose families have lower levels of schooling.

Statistical analysis shows a significant difference (Pillae' Trace $=0.013 ; \mathrm{F}(4,1030)=1.629 ; p=0.165)$. This difference is demonstrated in the perception of "family social support" ( $F$ $(2,515)=2.969 ; p=0.052)$ and between the group whose parents

Table 7.

School behavior and perceived social support.

\begin{tabular}{cccccccc}
\hline \multirow{2}{*}{ Behaviour } & \multicolumn{3}{c}{ Family support } & \multicolumn{3}{c}{ Peers support } \\
\cline { 2 - 7 } & $\mathrm{N}$ & $\mathrm{M}$ & $\mathrm{Sd}$ & $\mathrm{N}$ & $\mathrm{M}$ & $\mathrm{Sd}$ \\
\hline Always well behaved & 237 & 13.03 & 4.808 & 236 & 14.94 & 3.889 \\
Reasonably well behaved & 201 & 13.12 & 4.317 & 200 & 14.72 & 3.874 \\
Often badly behaved & 91 & 12.89 & 4.691 & 90 & 14.67 & 3.500 \\
\hline
\end{tabular}

Table 8.

Level of schooling and perceived parenting style.

\begin{tabular}{llllllllll}
\hline \multirow{2}{*}{$\begin{array}{l}\text { Level of } \\
\text { schooling }\end{array}$} & \multicolumn{3}{l}{ Permissive style } & \multicolumn{3}{c}{ Democratic style } & \multicolumn{3}{c}{ Authoritarian style } \\
\cline { 2 - 10 } & $\mathrm{N}$ & $\mathrm{M}$ & $\mathrm{Sd}$ & $\mathrm{N}$ & $\mathrm{M}$ & $\mathrm{Sd}$ & $\mathrm{N}$ & $\mathrm{M}$ & $\mathrm{Sd}$ \\
\hline Basic & 243 & 29.20 & 6.023 & 142 & 36.20 & 6.136 & 245 & 30.47 & 6.272 \\
Middle & 185 & 28.86 & 5.671 & 188 & 38.00 & 6.325 & 184 & 30.79 & 6.738 \\
Higher & 98 & 28.22 & 4.785 & 99 & 37.34 & 5.922 & 98 & 29.37 & 6.565 \\
\hline
\end{tabular}

Table 9.

Level of schooling and perceived social support.

\begin{tabular}{ccccccc}
\hline \multirow{2}{*}{ Level of schooling } & \multicolumn{3}{c}{ Family support } & \multicolumn{3}{c}{ Peers support } \\
\cline { 2 - 7 } & $\mathrm{N}$ & $\mathrm{M}$ & $\mathrm{Sd}$ & $\mathrm{N}$ & $\mathrm{M}$ & $\mathrm{Sd}$ \\
\hline Basic & 243 & 12.60 & 4.494 & 238 & 14.55 & 3.667 \\
Middle & 185 & 13.21 & 4.765 & 186 & 15.05 & 4.008 \\
Higher & 98 & 13.92 & 4.350 & 98 & 15.08 & 3.765 \\
\hline
\end{tabular}


Table 10.

Gender and perceived parenting style.

\begin{tabular}{lllll}
\hline Parenting style & Gender & N & Mean & Standard deviation \\
\hline \multirow{2}{*}{ Authoritarian } & Male & 258 & 30.86 & 6.597 \\
& Female & 273 & 29.86 & 6.399 \\
\multirow{2}{*}{ Permissive } & Male & 254 & 30.05 & 5.704 \\
\multirow{2}{*}{ Democratic } & Female & 276 & 27.90 & 5.470 \\
& Male & 256 & 37.77 & 5.579 \\
& Female & 277 & 36.36 & 6.651 \\
\hline
\end{tabular}

Table 11.

Gender and perceived social support.

\begin{tabular}{lllll}
\hline Social support & Gender & $\mathrm{N}$ & Mean & Standard deviation \\
\hline \multirow{2}{*}{ Family } & Male & 253 & 13.37 & 4.158 \\
& Female & 276 & 12.73 & 4.957 \\
\multirow{2}{*}{ Peers } & Male & 252 & 13.88 & 3.938 \\
& Female & 274 & 15.67 & 3.489 \\
\hline
\end{tabular}

have "basic level of schooling" and the group whose parents have "higher level of schooling" ( $p=0.047)$.

Finally, considering the data that measures the relationship between "gender" and "parenting style" as shown in Table 10, we can conclude that:

- "Democratic" style is perceived as the most often used by parents of both genders. However, boys perceive their parents as more "democratic" than girls $(\mathrm{t}(526)=2.663$; $p=$ 0.008).

- Both genders perceive their parents as more authoritarian than permissive;

- Girls perceive their parents as less permissive than boys ( $\mathrm{t}$ $(528)=4.434 ; p<0.001)$.

Taking into consideration the relationship between "gender" and perceived "social support", the analysis of data in Table $\mathbf{1 1}$ allows us to emphasize some aspects.

- Boys and girls admit to obtaining more support from peers than from their family. Among girls, this difference is statically significant $(\mathrm{t}(271)=-9.942 ; p<0.001)$.

- Girls perceive themselves as receiving more support than boys $(\mathrm{t}(503)=-5.513 ; p<0.001)$.

\section{Discussion and Conclusions}

Considering the study's objectives and the data analysis carried out, we may conclude that, in general, the Portuguese adolescent population surveyed perceives their parents as using predominantly a democratic style. Despite its values being close to authoritarian style, permissive style is viewed as the least often used. According to the literature (e.g. Yeh \& Lempers, 2004), a democratic parental style may contribute to the development of individual's abilities to manage negative or threatening experiences, significant events and relationships with partners effectively.

Regarding social support, adolescents perceive greater support from their peers than from their family, corroborating data gathered by Antunes and Fontaine (1994), and Gouveia Pereira, Pedro, Amaral, Alves Martins, and Peixoto (2000).

The analysis of the relationship between perceived school behavior and parenting styles shows that, in addition to the predominance of the democratic style, well-behaved adolescents perceive their parents as less permissive. On the other hand, those who reveal worse behavior are those who perceive their parents as more permissive and authoritarian. The pattern identified, which suggests that students who misbehavior may perceive their parents as more permissive was also observed in studies by Lamborn et al. (1991), Darling (1999), Oliveira (2002) and Lopes (2003). Moreover, we might also point out that those adolescents who exhibit more disruptive behavior in school settings and perceive their parents as being more authoritarian is also mentioned by Veiga (2002), and Aquilino and Supple (2001).

As regards the relationship between perceived school behavior and social support, worth mentioning that the three groups recognize receiving greater support by peers than family. In the same sense, we also noted that adolescents who "often behave badly" are those who refer to less social support, either from the family or peers.

Considering the variable "parent level of schooling" and analyzing their relationship with parenting styles, we concluded that the democratic style is more highly perceived and the permissive style shows a lower value. Moreover, parents who have a "higher level of schooling" are less often perceived as permissive or authoritarian, and this result is also revealed by Dornbusch et al. (1987) and corroborates the work conducted by Sonuga-Barke, Harrison and Hart (2000).

The relationship between perceived "level of schooling" and social support shows that adolescents recognize more support from their peers than from their family, and adolescents whose parents have a "high level of schooling" are those who relate more to social support given by the family.

Findings based on the relationship between gender and parenting style shows that democratic style emerges as predominant, although girls significantly have identified their parents as less "democratic" than boys. Moreover, they perceive their parents as significantly less permissive.

The present study supports earlier findings regarding the relationship between social support and school behavior. Both girls and boys admit having more support from their peers than from their family, and we found a significant difference between genders in social support received from peers, namely girls perceiving more social support. This data pattern is in agreement with studies developed by Fletcher et al. (1995), Helsen, Vollebergh e Meeurs (2000), Crosnoe (2001), and Crosnoe and Elder (2004).

This study has added knowledge concerning Portuguese adolescents' perceptions of the relationship between parenting styles and school behavior. However, future research is needed in order to readjust the parenting style model adopted and include the rejecting/negligent style in the analysis of the influence of parenting styles on Portuguese adolescent's school behavior.

\section{REFERENCES}

Alcón, M. C. (2002). Estilos educativos paternos: Descriptión e impacto diferencial en los patrones de desarollo de ninos com capacidad intellectual normal y ninos superdotados. Revista de Ciências de la educación, 189, 75-93.

Antunes, C., \& Fontaine, A. N. (1994). Diferenças na percepção de apoio social na adolescência: Adaptação de uma escala, o "Social Support Appraisals” de Vaux et al. (1980). Cadernos de Consulta Psicológica, 10, 115-127.

Aquilino, W. E., \& Supple, A. J. (2001). Long-term effects of parenting practices during adolescence on well-being outcomes in young adulthood. Journal of Family Issues, 22, 289-308. 


\section{doi:10.1177/019251301022003002}

Baumrind, D. (1967). Child care practices anteceding three patterns of the preschool behavior. Genetic Psychology Monographs, 75, 43-88.

Baumrind, D. (1973). The development of instrumental competence through socialization. In A. Pick (Ed.), Minnesota symposia on child psychology (pp. 3-46). Minneapolis: University of Minnesota Press.

Baumrind, D. (1991). The influence of parenting style on adolescence competency and substance use. The Journal of Early Adolescence, 11, 56-95. doi:10.1177/0272431691111004

Baumrind, D. (2005). Patterns of parental authority and adolescent autonomy. New Directions for Child and Adolescent Development, 108, 61-69. doi:10.1002/cd.128

Bernier, A., Larose, S., Boivin, M., \& Soucy, N. (2004). Attachment state of mind: Implications of adjustment to college. Journal of Adolescent Research, 19, 783-806. doi:10.1177/0743558403260096

Brendt, E. J. (1989). Obtaining support from friends during childhood and adolescence. In D. Belle (Ed.), Features of friendship and types of social support (pp. 308-331). New York: Wiley Pub.

Buri, J. R. (1991). Parental authority questionnaire. Journal of Personality and Social Assessment, 57, 110-119. doi:10.1207/s15327752jpa5701_13

Ciariano, S., Kliewer, W., Bonino, S., \& Bosma, H. A. (2008). Parenting and adolescent well-being in two European countries. Adolescence, 43, 99-117.

Colarossi, L. G., \& Eccles, J. (2000). A prospective study of adolescent's peer support: Gender differences and the influence of parental relationships. Journal of Youth and Adolescence, 29, 661-678. doi:10.1023/A:1026403922442

Cole, M., \& Cole, S. R. (2001). The development of children (4th ed.). New York: Worth Publishers.

Corcoran, K., \& Fisher, J. (2000). Measures for clinical practice: A source book (3rd ed.). New York: The Free Press.

Crosnoe, R. (2001). Academic orientation and parental involvement in education during high school. Sociology of Education, 74, 210-230. doi: $10.2307 / 2673275$

Crosnoe, R., \& Elder, G. (2004). Family dinamics, supportive relationships and educational resilience during adolescence. Journal of Family Issues, 25, 571-602. doi:10.1177/0192513X03258307

Darling, N., \& Steinberg, L. (1993). Parenting style as context: An integrative model. Psychological Bulletin, 113, 487-493. doi:10.1037/0033-2909.113.3.487

Darling, N. (1999). Parenting style and its correlates. Eric Digest. http://www.ericdigests.org/1999-4/parenting.htm

Dornbusch, S. M., Ritter, P. L., Leiderman, P. H., Roberts, D. F., \& Fraleigh, M. J. (1987). The relation of parenting style to adolescent school performance. Child Development, 58, 1244-1257. doi:10.2307/1130618

Durbin, D. L., Darling, N., Steinberg, L., \& Brown, B. B. (1993). Parenting style and peer group membership among European-American adolescents. Journal of Research on Adolescence, 3, 87-100. doi:10.1207/s15327795jra0301_5

Fletcher, A. C., Darling, N. E., Steinberg, L., \& Dornbusch, S. M. (1995). The company they keep: Relation of adolescent's adjustment and behaviour to their friend's perceptions of authoritative parenting in the social network. Developmental Psychology, 31, 300-310. doi:10.1037/0012-1649.31.2.300

Fonseca, H. (2002). Compreender os adolescentes. Lisboa: Editorial Presença.

Fontaine, A. M. (1995). Estilos educativos familiares e representações recíprocas dos pais e dos adolescentes. Actas do II Congresso da Sociedade Portuguesa de Ciências da Educação (pp. 195-208). Sociedade Portuguesa de Ciências da Educação.

Glasgow, K. L., Dornbusch, S. M., Troyer, L., Steinberg, L., \& Ritter, P. L. (1997). Parenting styles, adolescent's attributions, and educational outcomes in nine heterogeneous schools. Child Development, 68, 507-529. doi:10.2307/1131675

Gouveia Pereira, M., Pedro, I., Amaral, V., Alves Martins, M., \&
Peixoto, F. (2000). Dinâmicas grupais na adolescência. Análise Psicológica, 18, 191-201.

Grolnick, W. S. (2003). The psychology of parental control: How wellmeant parenting backfires. Mahwah, NJ: Erlbaum.

Helsen, M., Vollebergh, W., \& Meeurs, W. (2000). Social support from parents and friends and emotional problems in adolescense. Journal of Youth and Adolescence, 29, 319-335. doi:10.1023/A:1005147708827

Lamborn, S. D., Mounts, N. S., Steinberg, L., \& Ritter, P. L. (1991). Patterns of competence and adjustment among adolescents from authoritative, authoritarian, indulgent and neglectful families. Child Development, 62, 1094-1065. doi:10.2307/1131151

Lopes, A. J. (2003). Problemas de comportamento, problemas de aprendizagem e problemas de ensinagem. Coimbra: Quarteto.

Matherne, M., \& Thomas, A. (2001). Family environment as a predictor of adolescence delinquency. Adolescence, 134, 655-664.

Matta, I. (2001). Psicologia do desenvolvimento e da aprendizagem. Lisboa: Universidade Aberta.

Morris, A. S., Silk, J. S., Steinberg, L., Myers, S. S., \& Robinson, L. R. (2007). The role of the family context in the development of emotion regulation. Social Development, 16, 361-388. doi:10.1111/j.1467-9507.2007.00389.x

Noller, P. (1990). Relations with parents in adolescence: Process and outcome. In R. Montemayor, G. R. Adams, \& T. P. Gullota (Eds.), From Childhood to Adolescence. A transitional period? (pp. 37-77). London: Sage Publishers.

Oliveira, J. H. (2002). (In)Disciplina na sala de aulas: Perspectiva de aluno e professores. Psicologia, Educação e Cultura, 6, 69-99.

Procidano, M. E., \& Heller, K. (1983). Measures of perceived social support from friends and from family: Three validation studies. American Journal of Community Psychology, 11, 1-24. doi:10.1007/BF00898416

Smetana, J. G. (1995). Parenting styles and conceptions of parental authority during adolescence. Child Development, 66, 299-316. doi:10.2307/1131579

Sonuga-Barke, E., Harriso, C., \& Hart, N. (2000). Expectativas parentais, características da criança e desenvolvimento: Um estudo exploratório com dados longitudinais. Psychologica, 24, 129-141.

Sprinthall, N. A., \& Collins, W. A. (2003). Psicologia do adolescente: Uma perspectiva desenvolvimentalista (3rd ed.). Lisboa: Fundação Calouste Gulbenkian.

Steinberg, L. (2001). We know some things: Parent-adolescent relationships in retrospect and prospect. Journal of Research on Adolescence, 11, 1-19. doi:10.1111/1532-7795.00001

Steinberg, L., Elmen, J. D., \& Mounts, N. S. (1989). Authoritative parenting, psychosocial maturity, and academic success among adolescents. Child Development, 60, 1425-1436. doi: $10.2307 / 1130932$

Steinberg, L., Mounts, N. S., Lamborn, S. D., \& Dornbusch, S. M. (1991). Authoritative parenting and adolescent adjustment across varied ecological niches. Journal of Research on Adolescence, 1, 19-36.

Steinberg, L., Lamborn, S. D., Dornbusch, S. M., \& Darling, N. (1992). Impact of parenting practices on adolescence achievement: Authoritative parenting, school involvement and encouragement to succeed. Child Development, 63, 1266-1281. doi:10.2307/1131532

Strecht, P. (2005). Vontade de Ser-Textos sobre a Adolescência. Lisboa: Assírio \& Alvim.

Veiga, F. H. (2002). Indisciplina e violência na escola—Práticas comunicacionais para professores e Pais. Coimbra: Livraria Almedina.

Wills, T. A., \& Cleary, S. D. (1996). How are social support effects mediated? A test with parental support and adolescence substance abuse. Journal of Personality and Social Psychology, 71, 937-952. doi:10.1037/0022-3514.71.5.937

Yeh, H. C., \& Lempers, J. D. (2004). Perceived sibling relationships and adolescent development. Journal of Youth and Adolescence, 33, 133-147. doi:10.1023/B:JOYO.0000013425.86424.0f 